\title{
The Assessment of the Quality of Water Treatment Plants Effluent of Basrah City for Irrigation
}

\author{
Dr. Ahmed Naseh Ahmed Hamdan \\ Engineering College, University of Basrah / Basrah / IRAQ. \\ Email: ahmed n ahmed2005@yahoo.com
}

\begin{abstract}
The study included the assessment of the quality of the effluent of water treatment plants for irrigation uses. Eleven water treatment plants were selected in Basrah city center and surrounding areas which are Al-bradaiah1, Al-bradaiah2, AlRibat, R-Zero, Garmma1, Garmma2, Al Maqil, Al Jubila, Shatt Al_Arab, Al Hartha, and Al Basrah unified. One sample monthly were taken from these stations' effluent during January to December 2013, and the water samples were analyzed for $\mathrm{pH}$, electrical conductivity (EC), alkalinity, calcium $\left(\mathrm{Ca}^{++}\right)$, magnesium $\left(\mathrm{Mg}^{++}\right)$, chloride $\left(\mathrm{Cl}^{-}\right)$, sulphate (SO4), total dissolved solids (TDS), sodium $\left(\mathrm{Na}^{+}\right)$, potassium $(\mathrm{K})$, bicarbonate(HCO3), and carbonate $\left(\mathrm{CO}^{-2}\right)$. Sodium Adsorption Ratio (SAR), Soluble Sodium Percentage (SSP), Exchangeable Sodium Percentage (ESP), Residual Sodium Carbonate (RSC) were calculated by using standard equations, but EC and SAR were plotted on Richard diagram it is illustrated that water samples of R- Zero and Al- Maqil located in the class of $\mathrm{C} 3-\mathrm{S} 1$ representing high salinity with low sodium, which can be used for irrigation to all soil types with a minimum risk of exchangeable sodium, water samples of Al- Bradaiah1, A1- Bradaiah2, Garmma1, Garmma2, Al Jubaila and Shatt Al-Arab located in the class of C4-S2, of very high salinity and medium sodium which is considered poor. Al- Basrah unified, Al Hartha and Al Ribat located in the class of C3-S2, of high salinity and medium sodium, which is considered as Marginal. The results of the study revealed that R- Zero, Al Maqil has a good water quality for irrigation and the rest need a more interesting in treatment, or reduce the rate of mixing with Shatt Al-Arab River.
\end{abstract}

Key words: Water treatment plant, Irrigation water, quality assessment, Piper diagram, Richard diagram, SAR

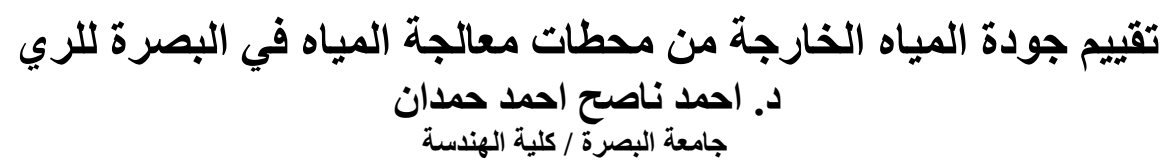

المستخلص

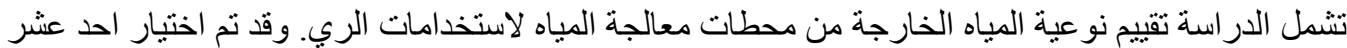

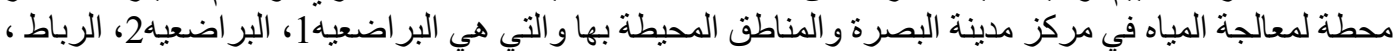

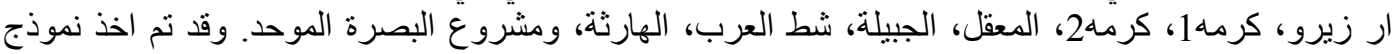

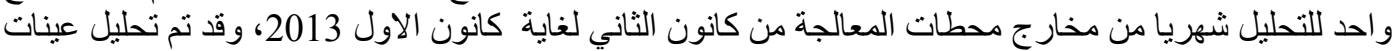

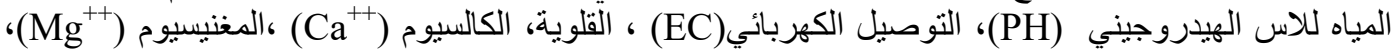




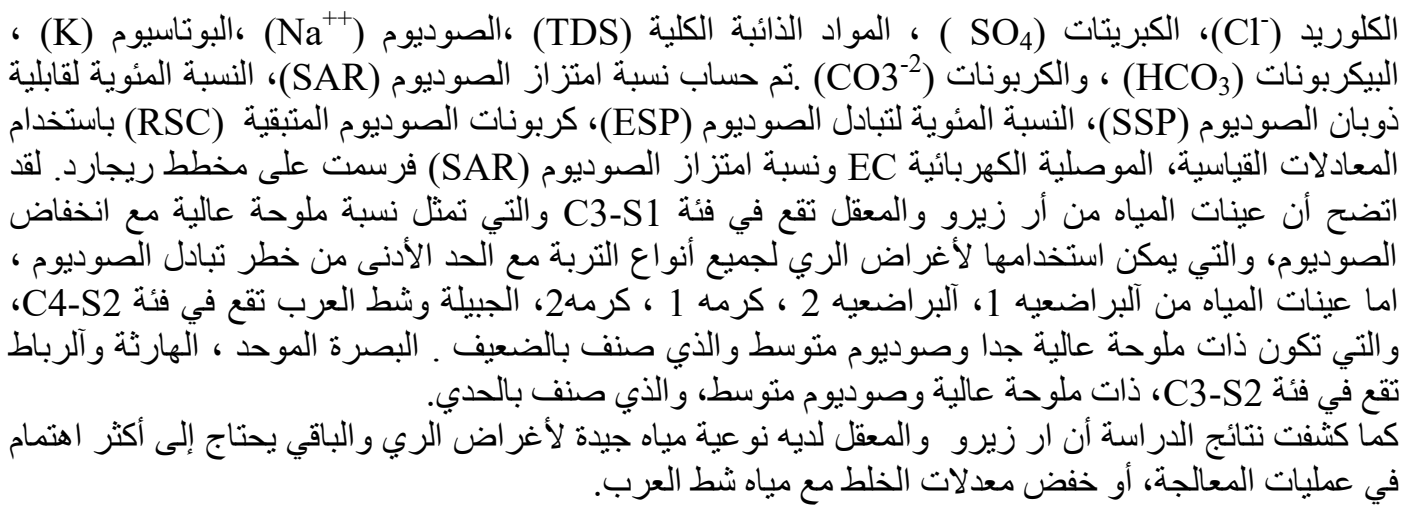

\section{Introduction}

Basrah is the second largest city in Iraq and has had a water supply problem for decades. Basrah governorate with a population of more than two million is located at the farthest downstream end of the Euphrates-Tigris river system. Historically the urban areas in the governorate obtained their water supply from adjacent surface waters. In Basrah, the Shatt al Arab River served as the main source for water supply. There is several treatment plants located alongside Shatt Al Arab River and some further away. Most of these plants are old, conventional treatment plants, due to the increase in total dissolved solids (TDS) to the level of more than $2000 \mathrm{mg} / 1$ and an increase in contamination levels, an alternate source of water had to be found. This new source was the Gharraf River, which is a tributary of the Tigris, but with a TDS level of about 700 $\mathrm{mg} / \mathrm{l}$ which made it acceptable as a source for drinking water. In the 1990's Sweet Water Canal (SWC), was constructed to bring this new source of water to Basrah. This untreated water flowed to a point (R-Zero) just west of Basrah. Some of the water was treated near R-Zero, but most of it was piped to the intakes of existing plants in Basrah and other cities in the governorate where it replaced the water formerly withdrawn from Shatt Al Arab river or the adjacent stretches of the Euphrates river. Water treatment in the governorate uses the conventional coagulation-filtration process which is suited for most surface water but will not lower TDS levels. Since people begin to notice and find disagreeable TDS levels which is in the range of 800 to $1500 \mathrm{mg} / \mathrm{l} \mathrm{range,} \mathrm{or} \mathrm{more} \mathrm{than}$ that in certain days of the year. In general the treated water quality at the tap is poor and is only acceptable for purposes other than drinking and cooking. Drinking water is usually purchased (RO water) from private suppliers in containers or delivered in bulk by tanker. Agriculture areas such as homes' garden is dependent on treated water supply of usable quality for Irrigation, but it has seen in recent years a deteriorate in agriculture. The suitability of water for irrigation depends on a variety of factors, most relevant and important are; salinity concentration of Total Dissolved Solid (TDS), expressed in EC unit, in irrigation water, which mainly affects crop yields, element toxicity concentration of certain ions, which may be toxic to plants or have unfavorable effects on crops, soils and public health and sodality concentration of cations, which may cause de-flocculation of clays in soils resulting damage to soil structure and permeability (SAR). The suitability of water for irrigation varies according to crops, 
types and permeability of soils and climate. Therefore irrigation water quality criteria developed by US salinity laboratory has received acceptance in many countries [1]. The present study was mainly lead to measure and analyze the treated water which were come from conventional water treatment plant and multiple package units (MPUs) in Basrah city for availability for irrigation, water quality parameters of treated Water such as EC, TDS, Sodium adsorption ratio(SAR), Soluble Sodium Percentage(SSP), Exchangeable Sodium Percentage (ESP), Residual Sodium Carbonate (RSC), pH Affect, chloride hazard, Magnesium Hazard, and Sulfate that could probably impact food safety of irrigation crops.

\section{Potable Water Treatment}

Table 1 list the water treatment plants in the governorate of Basrah and some of nearest districts which is subsidiary to it, which give some details of the processes used at each plant. Most of the treatment plants receive raw water from R-Zero, located at the end of the Sweet Water Canal (SWC), The intake of the SWC is at Bada'a near Ash Shatra on the Gharraf River, a branch of the Tigris, north of An Nasiriya in the Governorate of Dhi Qar, The SWC ends near Al- Basra International Airport at a spot called R-Zero. Many of the plants are located near to Shatt al Arab River (SAA), (see Fig.1), and can also draw raw water from the Shatt al Arab River if required. Shatt Al Arab River was Basrah's original freshwater source and hence all the water treatment plants were constructed on its banks. However, the reduction of fresh flows from the Tigris and Euphrates Rivers over time resulted in seawater intrusion advancing inland, increasing the salinity of the Shatt Al Arab river water, also using the Iraqi river system as a point of discharge for agricultural drainage water and sewage has further aggravated the problem of water quality in the Shatt Al Arab river, increasing the TDS levels in Shatt Al Arab river from an average of $1,792 \mathrm{mg} / 1$ in 1997 to an average exceeded the $3,000 \mathrm{mg} / 1$ in the year of 2001, that's due to dams that were constructed on the Tigris and the Euphrates upstream of Basra in Iraq, Turkey, and Syria. Almost all water treatment plants use aluminum sulphate (alum) as a coagulant, but it is rarely fully effective because of dosing equipment breakdowns. Universal disinfection using chlorine gas is intended but very few items of dosing equipment function as designed.

Table 1: Water treatment plans in Basrah city

\begin{tabular}{|c|c|c|c|c|c|}
\hline Name & $\begin{array}{c}\text { LONGITUD } \\
\text { E }\end{array}$ & $\begin{array}{c}\text { LATITUD } \\
\mathbf{E}\end{array}$ & $\begin{array}{c}\text { Year } \\
\text { Start } \\
\mathbf{s}\end{array}$ & Water source & $\begin{array}{c}\text { Typ } \\
\mathbf{e}\end{array}$ \\
\hline Al-bradaiah & 47.855 & 30.503 & 1958 & SWC \& SAA & Con \\
\hline Al-bradaiah & 47.852 & 30.507 & 1963 & SWC \& SAA & Con \\
\hline Al-Ribat & 47.8305 & 30.535 & 1985 & SWC \& SAA & MP \\
\hline R-Zero & 47.7094 & 30.5302 & 2000 & SWC & MP \\
\hline Garmma 1 & 47.7455 & 30.5714 & 1986 & SWC \& Garmat Ali & MP \\
\hline Garma 2 & 47.765 & 30.576 & 1986 & SWC \& Garmat Ali & MP \\
\hline Al Maqil & 47.799 & 30.553 & 1936 & SWC \& SAA & Con \\
\hline \multicolumn{7}{|c}{38} & &
\end{tabular}




\begin{tabular}{|c|c|c|c|c|c|}
\hline Al Jubila & 47.8131 & 30.55 & 1986 & SWC \& SAA & Con \\
\hline Shatt Al & 47.857 & 30.537 & 2002 & SWC \& SAA & Con \\
\hline Al Hartha & 47.7572 & 30.65 & 1986 & SWC \& SAA & MP \\
\hline Al Basrah & 47.7483 & 30.6486 & 1978 & SWC \& SAA & Con \\
\hline
\end{tabular}

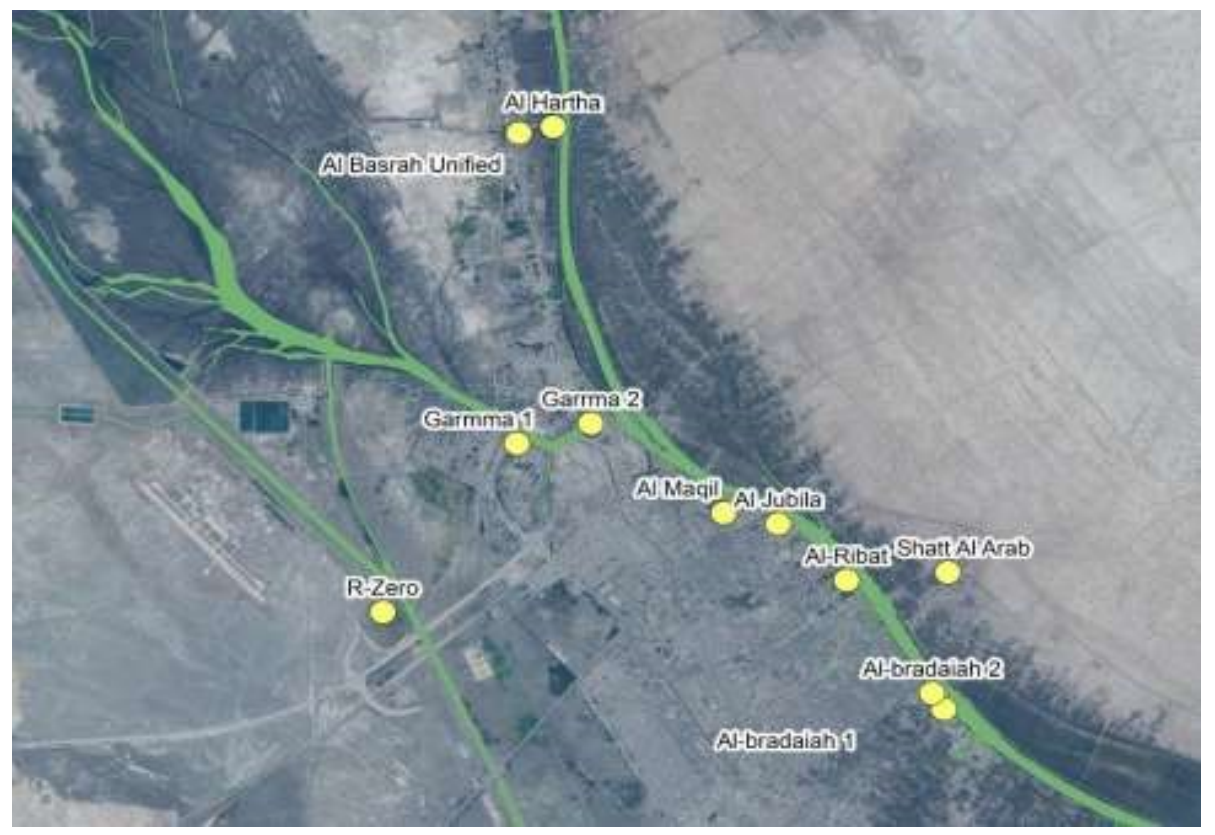

Fig.1: Water treatment plant locations in Center of Basrah city and surrounding areas.

\section{Methodology}

Eleven water treatment plant effluent were selected to study the availability of water supply for Basrah city to irrigate the agricultural areas, as shown in Fig.(1), The samples were taken monthly from each WTP during one year of 2013. Each sample was analyzed to determined twelve parameters including $\mathrm{pH}$, electrical conductivity (EC), alkalinity, calcium $\left(\mathrm{Ca}^{++}\right)$, magnesium $\left(\mathrm{Mg}^{++}\right)$, chloride $\left(\mathrm{Cl}^{-}\right)$, sulphate $\left(\mathrm{SO}_{4}\right)$, total dissolved solids (TDS), sodium $\left(\mathrm{Na}^{+}\right)$, potassium $(\mathrm{K})$, bicarbonate $\left(\mathrm{HCO}_{3}\right)$, and carbonate $\left(\mathrm{CO}_{3}{ }^{-2}\right)$, by using standard procedures guidelines from Examination of Water and Wastewater (APHA 1998), [2] . These parameters essentially consist of certain physical and chemical characteristics of water that are used in the assessment of water quality for agricultural. The suitability of water for drinking, domestic and irrigation purposes were assessment depending on the classification of US Salinity Laboratory (USSL) by calculating irrigation quality parameters like, Sodium adsorption ratio(SAR), Soluble Sodium Percentage(SSP), Exchangeable Sodium Percentage (ESR), Residual Sodium Carbonate (RSC), pH Affect, chloride hazard, Magnesium Hazard, and Sulfate. 
Correlation of analytical data has been attempted by plotting a graphical representation called Piper diagram [3].

\section{Irrigation Water Quality Assessment}

The characteristics of irrigation water which are important in determining its quality are:

\subsection{Salinity Hazard}

Salinity hazard is the main powerful water quality guideline on crop productivity as measured by electrical conductivity, it reflects TDS in water. The amount of water transpired through a crop is directly related to yield; therefore, irrigation water with high EC reduces yield potential and can result in a physiological drought condition. That is, even though the field appears to have plenty of moisture, the plants wilt because the roots are unable to absorb the water, Table 2, shown the criterion which used to assess the quality of water for use in agriculture concerning to salinity hazard.

Table 2: Salinity hazard guidelines for determination of water quality for irrigation Source FAO, 1985 [4]

\begin{tabular}{|c|c|c|c|c|}
\hline \multirow{2}{*}{$\begin{array}{c}\text { Potential irrigation } \\
\text { problem }\end{array}$} & \multirow{2}{*}{ Units } & \multicolumn{3}{|c|}{ Degree of restriction on use } \\
\cline { 3 - 5 } & & None & $\begin{array}{c}\text { Slight to } \\
\text { moderate }\end{array}$ & severe \\
\hline \multicolumn{5}{|c|}{ Salinity } \\
\hline EC $_{\mathrm{w}}$ & $\mathrm{ds} / \mathrm{m}$ & $<0.7$ & $0.7-3.0$ & $>3.0$ \\
\hline TDS & $\mathrm{mg} / 1$ & $<450$ & $450-2000$ & $>2000$ \\
\hline
\end{tabular}

\subsection{Sodium Hazard}

Sodium hazard is normally expressed as the sodium adsorption ratio (SAR). This index quantifies the proportion of sodium $\left(\mathrm{Na}^{+}\right)$to calcium $\left(\mathrm{Ca}^{+2}\right)$ and magnesium $\left(\mathrm{Mg}^{+2}\right)$ ions in a sample, SAR is considered a better measure of sodium hazard in irrigation as it is directly related to the adsorption of sodium by soil and prevent water supply which needed for the crops by reducing the permeability of soil [5], SAR is calculated using the equation:-

$$
S A R=\frac{N a}{\sqrt{(C a+M g) / 2}} \ldots \ldots \ldots \ldots \ldots \ldots \ldots \ldots \ldots \ldots
$$

Where,

$\mathrm{Na}^{+}, \mathrm{Ca}^{+2}$ and $\mathrm{Mg}^{+2}$ are in milli equivalent per liter ( meq/l ).

There is a major relationship between SAR values of irrigation water and the amount to which sodium is absorbed by the soils. Continued use of water with high SAR value leads to a breakdown in the physical structure of the soil caused by immoderate amounts of colloidal adsorbed sodium. The soil then becomes hard and compact when dry and increasingly impervious to water infiltration, Table 3 represent a classification of irrigation water based on SAR values. 


\section{Table 3. Irrigation water classification based on SAR values [6]}

\begin{tabular}{|c|c|c|}
\hline Level & SAR & Hazard \\
\hline S1 & $<10$ & No harmful effects from sodium. \\
\hline S2 & $10-18$ & $\begin{array}{r}\text { Appreciable sodium hazard in fine-textured soils but could be used } \\
\text { on sandy soils with good permeability. }\end{array}$ \\
\hline S3 & $18-26$ & $\begin{array}{c}\text { Harmful effects could be anticipated in most soils and amendments } \\
\text { such as gypsum would be necessary to exchange sodium ions. }\end{array}$ \\
\hline S4 & $\geq 26$ & Generally unsatisfactory for irrigation \\
\hline
\end{tabular}

\subsection{Soluble Sodium Percentage}

The sodium is particularly important among the positive ions due to a severe impact on the soil, where the soil contain sodium tends to dispersed and form a coherent crust where drought reduces the growth of plants and seedlings penetrate the Earth's surface, SSP and can be determined using the following equation:-

$$
100.2 * \mathrm{SSP}=\frac{\mathrm{Na}}{(\mathrm{Ca}+\mathrm{Mg}+\mathrm{Na}+\mathrm{K})} \ldots \ldots \ldots \ldots \ldots \ldots \ldots \ldots \ldots \ldots \ldots \ldots
$$

Where: all ionic concentrations are in meq/l.

Irrigation water with SSP greater than $60 \%$ may result in accumulation of sodium and probably deterioration the structure of soil, infiltration, aeration and reducing soil permeability [7].

\subsection{Exchangeable Sodium Percentage} deterioration.

Exchangeable Sodium Percentage (ESP) is an indicator for soil structure If ESP is high that's mean high sodium ion concentration in the water, and that's lead to dispersing soils by replacing the calcium and partly of the magnesium ions from soil exchange complex.

The required value of ESP is 5 or less than 5, if values of ESP between 6 and 9 mean increasing problems with permeability and soil infiltration, especially in clay soil, ESP values greater than 15 mean serious problems for soils [8].

ESP value for irrigation water can be determined from the following empirical equation:-

$$
\frac{(0.01475 \times \mathrm{SAR}-0.0126)}{(1+(0.01475 \times \mathrm{SAR}-0.0126))} \times 100
$$

From above three mentioned formulas, the ratio of SAR was adopted in most irrigation water classifications based on the risk of sodium. 


\subsection{Residual Sodium Carbonate}

The excess sum of carbonate and bicarbonate in the water over the sum of calcium and magnesium also affects the suitability of water for irrigation purposes. In the waters having high concentrations of bicarbonate, there is a tendency for calcium and magnesium to precipitate as the water in the soil becomes more concentrated. An excess quantity of carbonate and sodium bicarbonate is considered to be injurious to the physical properties of soils as it causes dissolution of organic matter in the soil, which in turn leaves a black stain on the soil surface on drying. Hence, the relative proportion of sodium in the water is increased in the form of sodium carbonate, denoted as residual sodium carbonate (RSC), [9] . Table (4), show RSC range values and corresponding potential use. RSC is determined by the following equation:- [10]

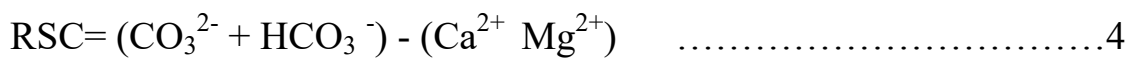

All ion concentrations are expressed in meq/l.

Table 4: Classification of irrigation water based on SAR values [6]

\begin{tabular}{|l|l|}
\hline RSC Value (meq/1) & Potential Use \\
\hline$\leq 1.25$ & Generally safe for irrigation. \\
\hline 1.25 to 2.5 & Marginal as an irrigation source \\
\hline$>2.5$ & Usually unsuitable for irrigation without amendment \\
\hline
\end{tabular}

\subsection{PH Affect}

Normal PH range of water for irrigation is between 6.5 to 8.4 , irrigation water with a $\mathrm{pH}$ outside the normal range may cause nutritional imbalance or may contain toxic ion, where low $\mathrm{pH}$ may cause accelerated irrigation system corrosion in which they occur. High $\mathrm{pH}$ above 8.5 are often cause accelerated irrigation system corrosion where they occur. High $\mathrm{pH}$ above 8.5 are often caused by high bicarbonate $\left(\mathrm{HCO}_{3}\right)$ and carbonate $\left(\mathrm{CO}_{3}^{-2}\right)$ concentrations [11].

\subsection{Chloride Hazard}

Chloride is a common ion in irrigation water. Although chloride is necessary to plant in very low amount, it can cause toxicity to sensitive crops at high concentration (see Table 5). If the chloride contamination in the leaves exceeds the tolerance of the crop, injury symptoms are developed such as leaf burn or drying of leaf tissue. These symptoms occur when leaves accumulate from 0.3 to 1.0 percent chloride. It is not absorbed by the soil but moves readily with the soil water [12]. 
Table 5: Irrigation Water Classification regarding to chloride

\begin{tabular}{|l|l|c|c|}
\hline \multirow{2}{*}{ Potential irrigation problem } & \multicolumn{3}{|c|}{ Degree of restriction on use } \\
\cline { 2 - 4 } & None & Slight to moderate & Severe \\
\hline Surface irrigation & $<4$ & $4-10$ & $>10$ \\
\hline Sprinkler irrigation & $<3$ & $>3$ & \\
\hline
\end{tabular}

\subsection{Magnesium Hazard}

Calcium and magnesium ions are essential for plant growth but they may be related with soil aggregation and friability. High concentration of calcium and magnesium in irrigation water might be leads to increase soil $\mathrm{pH}$, resulting in reducing availability of phosphorus. Water contains calcium and magnesium concentration higher than $10 \mathrm{meq} / 1$ $(200 \mathrm{mg} / \mathrm{l})$ cannot be used in agriculture. Magnesium ion concentration also plays an important role in productivity of soil. It has been noted that if magnesium hazard is less than 50, the water is safe and suitable for irrigation. Magnesium hazard can be calculated from the following equation:

$$
\mathbf{M H}=\frac{M g}{\mathrm{Mg}+\mathrm{Ca}} * 100
$$

Where,

$\mathrm{Ca}$ and $\mathrm{Mg}$ ions are expressed in meq/1

\subsection{Sulfate}

Sulfate $\left(\mathrm{SO}_{4}\right)$ is relatively common in water and has no major effect on the soil other than contributing to the total salt content. If irrigation water contain high sulfate ions that leads to reduce phosphorus availability to plants. If $\mathrm{SO}_{4}$ less than $400 \mathrm{mg} / \mathrm{l}$ that mean a preferred range but higher than $400 \mathrm{mg} / \mathrm{l}$ will leads to acidify the soil[ 13].

\subsection{US Salinity Laboratory's diagram (Richard diagram)}

The US salinity diagram (Richard diagram), Fig.2 which is based on the combined effect of EC and SAR, has been used to assess the suitability of water for irrigation [10]. The diagram was divided into 16 areas that were used to rate the degree to which a particular water may give rise to salinity problems and undesirable ion exchange effects in soil (Hem, 1989), table 6, show classification of water samples according to Richard diagram . 


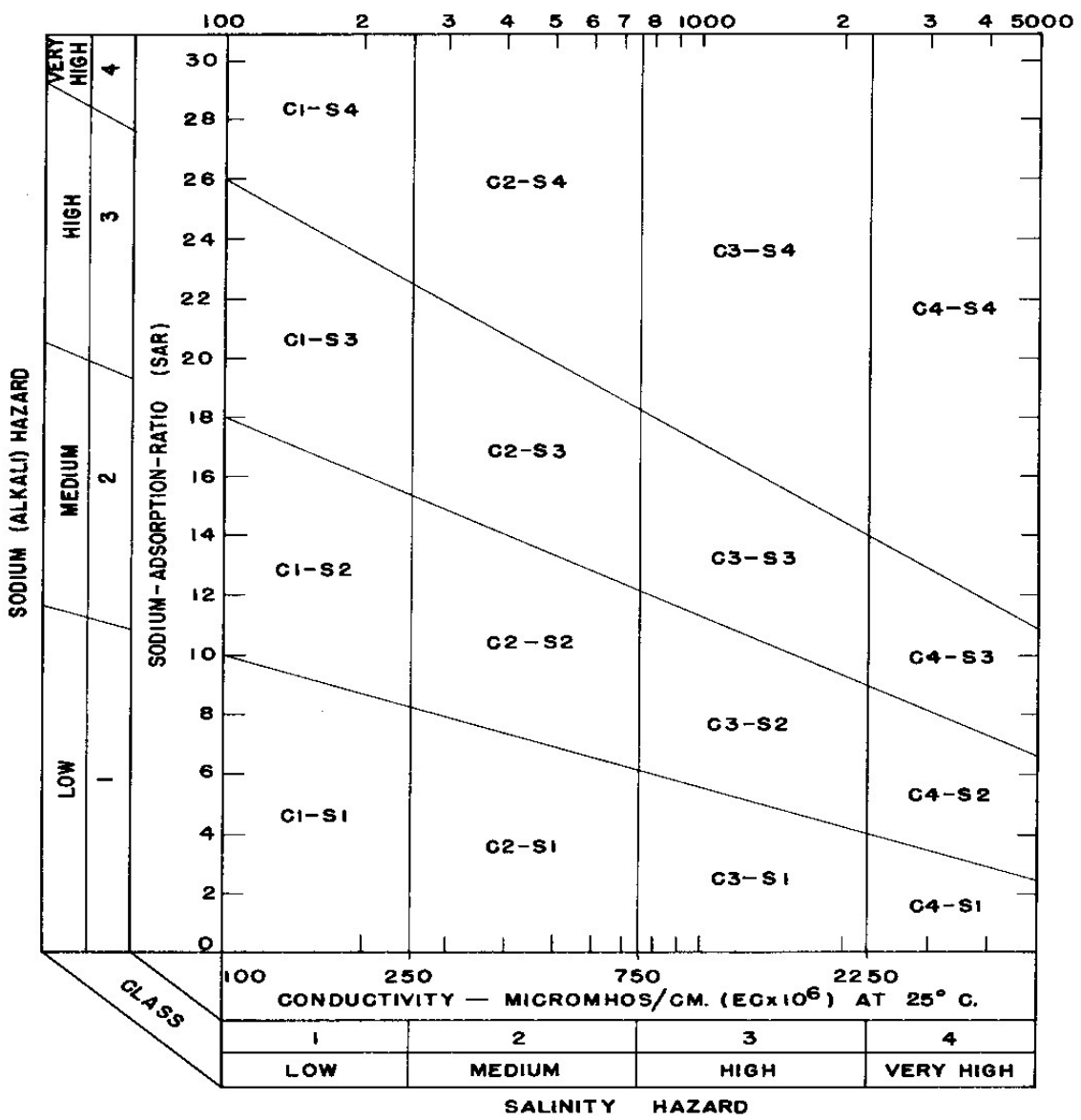

Fig.2:US Salinity Laboratory's diagram

Table 6 : Classification of water samples according to Richard Diagram

\begin{tabular}{|c|c|c|c|}
\hline Index & Water class & Index & Water class \\
\hline $\mathrm{C} 1 \mathrm{~S} 1$ & Excellent & C3S1 & Admissible \\
\hline $\mathrm{C} 1 \mathrm{~S} 2$ & Good & C3S2 & Marginal \\
\hline $\mathrm{C} 1 \mathrm{~S} 3$ & Admissible & C3S3 & Marginal \\
\hline $\mathrm{C} 1 \mathrm{~S} 4$ & Poor & C3S4 & Poor \\
\hline $\mathrm{C} 2 \mathrm{~S} 1$ & Good & C4S1 & Poor \\
\hline $\mathrm{C} 2 \mathrm{~S} 2$ & Good & C4S2 & Poor \\
\hline $\mathrm{C} 2 \mathrm{~S} 3$ & Marginal & C4S3 & Very Poor \\
\hline $\mathrm{C} 2 \mathrm{~S} 4$ & Admissible & C4S4 & Very Poor \\
\hline
\end{tabular}

\subsection{1 piper diagram}

piper diagram is a graphical representation of the chemistry of a water samples. Separate ternary plots show the cations and anions. The apexes of the cation plot are calcium, magnesium and sodium plus potassium cations. The apexes of the anion plot 
are sulphate, chloride and carbonate plus hydrogen carbonate anions. The two ternary plots are then projected onto a diamond. The diamond is a matrix transformation of a graph of the anions (sulfate + chloride/ total anions) and cations (sodium + potassium /total cations).

\section{Results and Discussion}

Statistical analysis of parameters for mean annual of year 2013, for physical and chemical characterization of the eleven stations samples are shown in Table 7.

Table. 7: major ions concentrations

\begin{tabular}{|c|c|c|c|c|c|c|c|c|c|c|c|}
\hline Name & PH & $\mathbf{E C}$ & $\mathbf{A l k}$ & $\mathbf{C a}$ & $\mathbf{S O}_{\mathbf{4}}$ & $\mathbf{T D S}$ & $\mathbf{N a}$ & $\mathbf{K}$ & $\mathbf{H C O}_{\mathbf{3}}$ & $\mathbf{C O}_{\mathbf{3}}$ & $\mathbf{C l}$ \\
\hline Al-bradiah 1 & & & & & & & & & & & \\
& 7.6 & 2644 & 153 & 131 & 476 & 1636 & 324 & 7.1 & 170 & 15 & 516 \\
\hline Al-bradiah 2 & 7.6 & 2255 & 146 & 122 & 418 & 1378 & 253 & 6.2 & 170 & 15 & 409 \\
\hline Al-Ribat & 7.6 & 2036 & 143 & 107 & 346 & 1242 & 233 & 5.6 & 130 & 14 & 383 \\
\hline R-Zero & 7.9 & 1104 & 130 & 88 & 226 & 655 & 65 & 3.2 & 100 & 9 & 133 \\
\hline Garmma 1 & 7.5 & 2471 & 146 & 128 & 454 & 1520 & 277 & 6.6 & 120 & 10 & 464 \\
\hline Garrma 2 & 7.6 & 2476 & 146 & 128 & 453 & 1528 & 284 & 7 & 120 & 9.6 & 472 \\
\hline Al Maqil & 7.6 & 1241 & 132 & 90 & 321 & 736 & 90 & 3.7 & 125 & 11 & 170 \\
\hline Al Jubila & 7.6 & 2654 & 142 & 103 & 531 & 1052 & 175 & 4.8 & 130 & 11.4 & 293 \\
\hline Shatt Al Arab & 7.6 & 2599 & 154 & 131 & 456 & 1600 & 314 & 7.1 & 150 & 15 & 459 \\
\hline Al Hartha & 7.7 & 2027 & 151 & 113 & 373 & 1226 & 217 & 5.3 & 98 & 9 & 353 \\
\hline $\begin{array}{c}\text { Al Basrah } \\
\text { Unified }\end{array}$ & 7.8 & 1890 & 149 & 106 & 338 & 1148 & 204 & 4.9 & 100 & 9.3 & 330 \\
\hline
\end{tabular}

Table 7 shows that, minimum Electrical conductivity (EC) of water was in RZero station which was $1104 \mu \mathrm{S} / \mathrm{cm}=1.104 \mathrm{dS} / \mathrm{m}$ and maximum EC was in Al- Jubila station which was $2654 \mu \mathrm{S} / \mathrm{cm}=2.654 \mathrm{dS} / \mathrm{m}$, ( see Fig. 3), All stations were in slight to moderate range as shown in table 2. Minimum TDS was in R Zero which equals to 655 $\mathrm{mg} / \mathrm{l}$ and the maximum was in Al-bradiah1 which was equal to $1636 \mathrm{mg} /$, (see Fig.4). All stations were located in slight to moderate range as illustrated in table 2. For chloride concentrations $\left(\mathrm{Cl}^{-}\right)$all samples ranged from $(133$ to $516 \mathrm{mg} / \mathrm{l})$, the minimum value was in $\mathrm{R}$ - zero $(133 \mathrm{mg} / \mathrm{l}=3.75 \mathrm{meq} / \mathrm{l})$ and the maximum value was in Albradiah1 $(516 \mathrm{mg} / \mathrm{l}=14.56 \mathrm{meq} / \mathrm{l})$, the irrigation water classification regarding to chloride (table 5), shows that R-zero indicates a none degree of restriction on use for surface irrigation and slight to moderate degree of restriction for sprinkler irrigation. Al Jubaila, Al-Maqil, Al-Hartha and Al Basrah unified, are located in the range of slight to moderate degree, and the rest were greater than $10 \mathrm{meq} / \mathrm{l}$ and this was unsuitable for tolerant plants. The stations of Al-bradiah1, Al-bradiah2, Garmma1, Garmma2, A1 Jubila and Shatt Al Arab have values of SO4 greater than $400 \mathrm{mg} / \mathrm{l}$, indicating a problem of acidifying the soil, and the rest are good and suitable for irrigation purposes. 


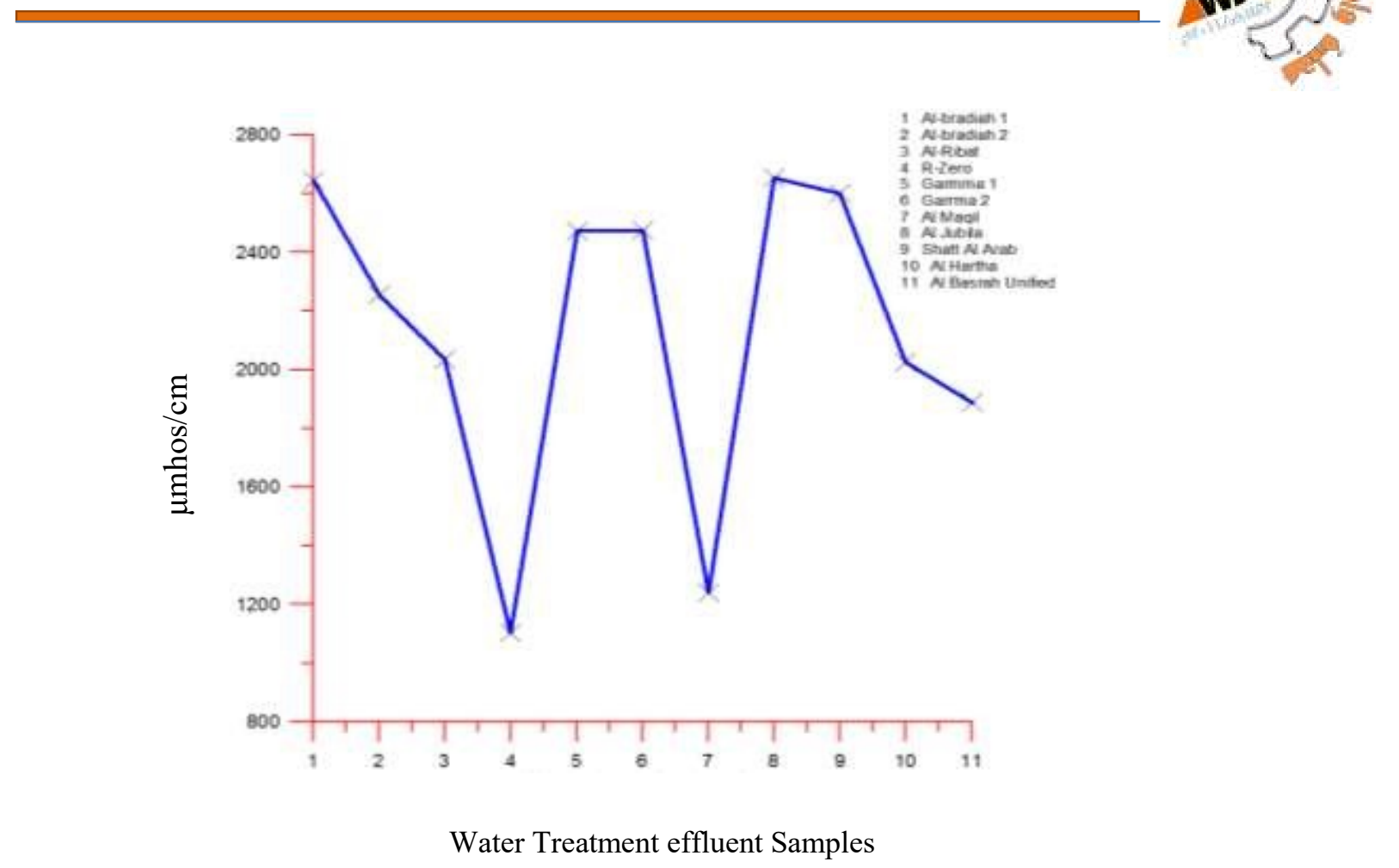

Fig 3: Annual average values of EC for WTP samples during the year of study.

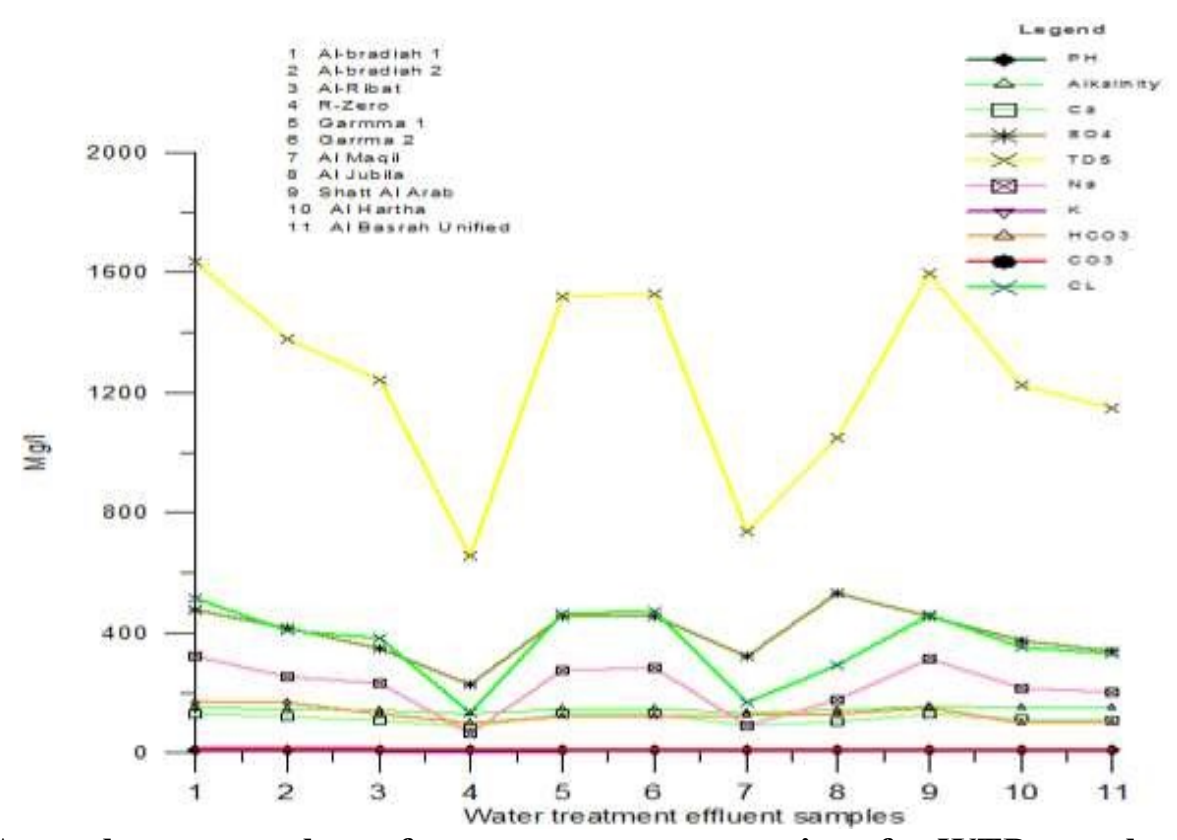

Fig 4: Annual average values of parameters concentrations for WTP samples during the year of study. 
It was observed from table 8 that, for SAR in all stations ranged from 1.4 to 5.5, the minimum value was in station R-Zero, and the maximum value was in station AlBradaiah1. All stations are classified as having no harmful effects of sodium, regarding sodium hazard as shown in table 3. No samples have SSP greater than $60 \%$. Therefore, the water is safe from accumulation and deterioration of soil structure. Only R-Zero, Al-Ribat, Al-Jubaila, Hartha, Al Basrah unified and Al-Maqil, have ESP less than 5 and has no problem in soil infiltration and permeability. All water samples were less than 1.25 for RSC. Thus, regarding to carbonate and bicarbonate levels, all samples are safe for irrigation. $\mathrm{pH}$ of all stations varies from 7.5 to 7.9 , which indicates that $\mathrm{pH}$ is within normal range. Al Bradhaial and Garmmal exceed the value of $50 \%$ of Magnesium Hazard (MH), and the rest is under the allowable ratio and therefore they are suitable for irrigation.

Table 8: Irrigation Quality Characteristics Calculation.

\begin{tabular}{|c|c|c|c|c|c|c|}
\hline Station & $\begin{array}{c}\text { Sodium } \\
\text { Adsorptio } \\
\text { n Ratio } \\
\text { (SAR) }\end{array}$ & $\begin{array}{c}\text { Soluble } \\
\text { Sodium } \\
\text { Percenta } \\
\text { ge } \\
\text { SSP }\end{array}$ & $\begin{array}{c}\text { Exchangea } \\
\text { ble Sodium } \\
\text { Percentage } \\
\text { (ESP) }\end{array}$ & $\begin{array}{c}\text { Residual } \\
\text { Sodium } \\
\text { Carbona } \\
\text { te } \\
\text { (RSC) }\end{array}$ & PH & $\begin{array}{c}\text { Magnesiu } \\
\text { m Hazard }\end{array}$ \\
\hline Al- Bradhiaia1 & 5.5 & 51.544 & 6.444 & -9.832 & 7.6 & 50.2 \\
\hline Al- Bradhiaia2 & 4.51 & 47.752 & 5.135 & -8.642 & 7.6 & 49 \\
\hline Al- Ribat & 4.4 & 48.629 & 4.995 & -8.007 & 7.6 & 49.7 \\
\hline R-Zero & 1.4 & 25.580 & 0.804 & -6.236 & 7.9 & 46.3 \\
\hline Garmma 1 & 4.76 & 48.250 & 5.474 & -10.504 & 7.5 & 50.1 \\
\hline Garmma 2 & 4.9 & 49.012 & 5.654 & -10.435 & 7.6 & 49.8 \\
\hline Al-Maqel & 1.88 & 30.917 & 1.499 & -6.271 & 7.6 & 48.3 \\
\hline Al-Jubaila & 3.39 & 42.834 & 3.625 & -7.565 & 7.6 & 49 \\
\hline Shatt- Al Arab & 5.38 & 51.229 & 6.290 & -9.913 & 7.6 & 49.2 \\
\hline Al - Hartha & 4.01 & 45.821 & 4.472 & -9.162 & 7.7 & 49.1 \\
\hline Al- Basrah & 3.91 & 46.057 & 4.332 & -8.359 & 7.8 & 48.7 \\
\hline
\end{tabular}

When the analytical data of EC and SAR plotted on the Richard diagram (Fig.5), it is illustrated that water samples of R- Zero and Al- Maqil, located in the class of C3S1 which are considered as "admissible" regarding to Richard classification (see table 6), they represent high salinity with low sodium, which can be used for irrigation on all types of soil with only a low risk of exchangeable sodium, water samples of A1Bradaiah1, Al- Bradaiah2, Garmma1 , Garmma2, Al Jubaila and Shatt Al-Arab located in the class of C4-S2 which are considered as "Poor" regarding to Richard classification, they represent very high salinity and medium sodium. Generally class C4 is unsuitable for irrigation, but may sometimes be used under very special situations, such as when the soils must be porous, drainage must be adequate, irrigation water must be applied in excess to provide considerable filtrate, and very salt-tolerant crops should be selected. Al- Basrah Unified, Al Hartha and Al Ribat are located in the class of C3-S2, of high 
salinity and medium sodium, which is considered as "Marginal" regarding to Richard, classification [4].

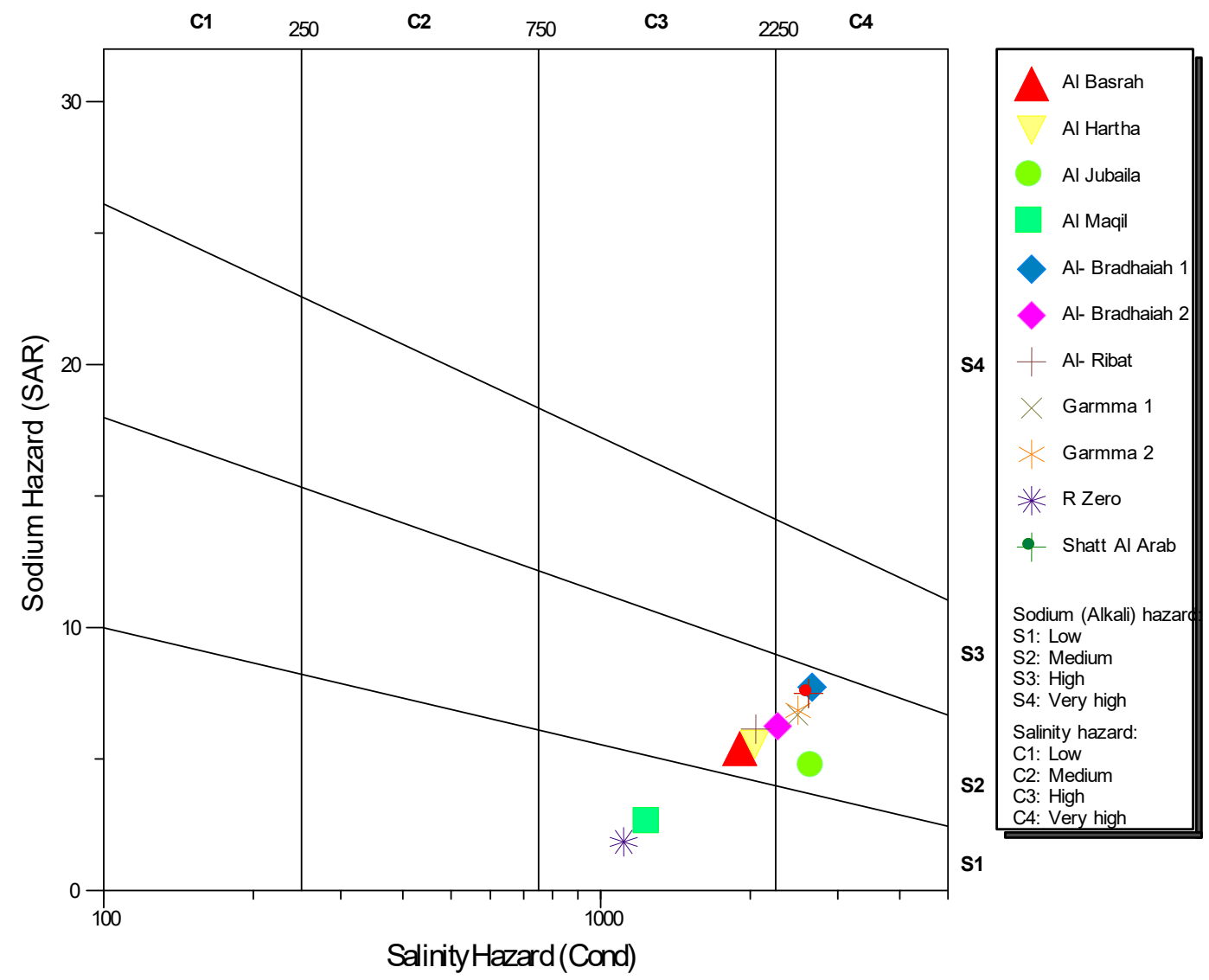

Fig. 5: Water samples evaluation in relation to salinity and sodium hazard

The values of $\mathrm{Cl}^{-}, \mathrm{SO}^{-2}, \mathrm{Ca}^{+2}, \mathrm{Na}^{+}, \mathrm{K}^{+}, \mathrm{Co} 3, \mathrm{HCO}^{-}$and $\mathrm{Mg}^{+2}$ for each sample were plotted on a Piper diagram to indicate the type of water and overall composition and trends for the sample [14]. For plotting Piper diagram, the Schlumberger water services AquaChem software version, 2015, 1.5.0 software was used to display the relative concentrations of the different ions from individual water samples for the study area. Piper diagram for the study area is given in Fig 6. A software report was classified the water type and salinity hazard as shown in table 9, the measures are included between $\mathrm{Ca}-\mathrm{SO} 4$ facies, which is typical of sodium bicarbonate water for fluvial origin (by dissolution of gypsum and other rocks) these were found in R- Zero and Al Maqil stations, and $\mathrm{NaCl}$ facies, which is typical of sea origin (i.e. they indicate the presence of brackish water), that is due to the effect of Shatt Al Arab river for these stations. 

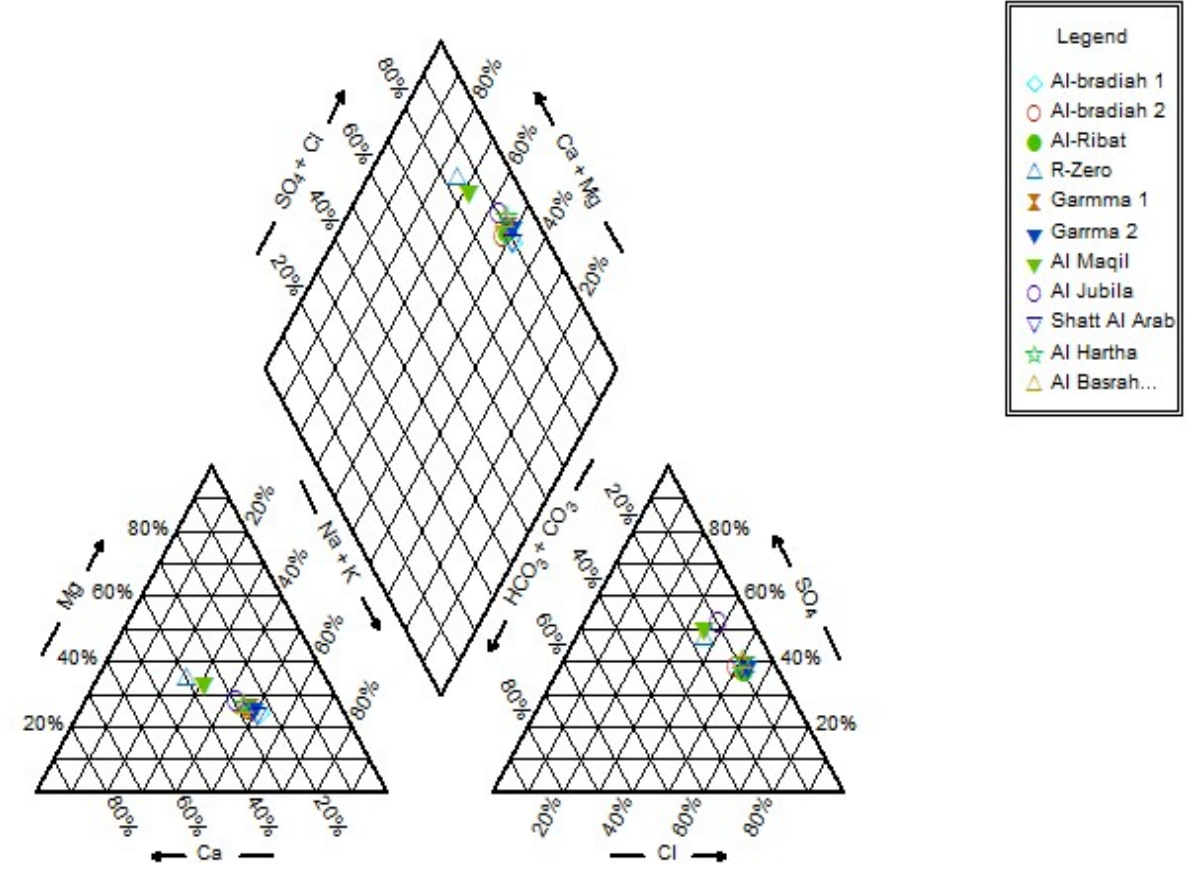

Fig. 6: Piper diagram for water treatment plant effluent samples

Table 9: Chemical type of water sample according to piper diagram

\begin{tabular}{|c|c|c|}
\hline Station & Water Type & Salinity Hazard \\
\hline Al- Bradhiaia1 & $\mathrm{Na}-\mathrm{Cl}$ & Very High \\
\hline Al- Bradhiaia2 & $\mathrm{Na}-\mathrm{Cl}$ & Very High \\
\hline Al- Ribat & $\mathrm{Na}-\mathrm{Cl}$ & High \\
\hline R-Zero & $\mathrm{Ca}-\mathrm{SO}_{4}$ & High \\
\hline Garmma 1 & $\mathrm{Na}-\mathrm{Cl}$ & Very High \\
\hline Garmma 2 & $\mathrm{Na-Cl}$ & Very High \\
\hline Al-Maqel & $\mathrm{Ca}-\mathrm{SO} 4$ & High \\
\hline Al-Jubaila & $\mathrm{Na}-\mathrm{So} 4$ & Very High \\
\hline Shatt- Al Arab & $\mathrm{Na}-\mathrm{Cl}$ & Very High \\
\hline Al- Hartha & $\mathrm{Na}-\mathrm{Cl}$ & High \\
\hline Al- Basrah Unified & $\mathrm{Na}-\mathrm{Cl}$ & High \\
\hline
\end{tabular}

\section{Conclusions}

The ultimate conclusions of the research are:

1. All stations were in slight to moderate rang regarding to Salinity hazard guidelines.

2. All stations are classified as having no harmful effects of sodium, regarding to sodium hazard. 
3. $\mathrm{Cl}^{-}$for $\mathrm{R}$ - Zero indicates a none degree of restriction on use of surface irrigation and slight to moderate degree of restriction of sprinkler irrigation, Al Jubaila, Al-Maqil, Al-Hartha and Al Basrah unified, located in the range of slight to moderate degree, and the rest are unsuitable for tolerant plants.

4. Stations of Al-bradiah 1, Al-bradiah 2, Garmma 1, Garmma 2, Al Jubila and Shatt Al Arab indicate a problem of acidifying the soil, and the rest are good and suitable for irrigation purposes.

5. No sample has SSP greater than $60 \%$, therefore all water samples for all stations were safe of accumulation and deterioration of soil structure.

6. Only R-Zero, Al-Ribat, Al-Jubaila, Hartha, Al Basrah unified and Al-Maqil, have ESP less than 5 and have no problem in soil infiltration and permeability.

7. All water samples were less than 1.25 for RSC, therefore all samples are safe for irrigation, regarding to carbonate and bicarbonate levels.

8. $\mathrm{pH}$ of all stations was within normal range.

9. Al Bradhaial and Garmmal exceed the value of $50 \%$ of Magnesium hazard $(\mathrm{MH})$, and the rest are under the allowable ratio and therefore they are suitable for irrigation.

10. water samples of R- Zero and Al- Maqil are located within class C3-S1 indicate high salinity with low sodium, which is considered "admissible" regarding to Richard diagram.

11. water samples of Al- Bradaiah1, Al- Bradaiah2, Garmma1 , Garmma2, Al Jubaila and Shatt Al-Arab are located within class of C4-S2, of very high salinity and medium sodium, which is considered "poor" regarding to Richard diagram.

12. Al-Basrah unified, Al Hartha and Al Ribat are located within class of C3-S2, of high salinity and medium sodium, which is considered "marginal" regarding to Richard diagram.

13. AquaChem software showed that the measures are ranged between fluvial origin for R-Zero and Al Maqil stations and sea origin for others that is due to effect of Shatt al Arab River for these stations.

14. R- Zero and Al Maqil have a good water quality for irrigation and the rest need a more considerate treatment.

\section{Suggestions}

1- The sustainable use of water treatment plant effluent water for agriculture can be considered arable for the areas irrigated by R-zero effluent or if water treatment plants pumped the water which taken from R-zero directly without mixing it with Shatt $\mathrm{Al}$ Arab river water.

2- Increasing the efficiency of water treatment plant, or more considerate treatment must be taken.

3- Improving water softening in water treatment plant for removal of calcium, magnesium, and certain other metal cations in hard water. 


\section{References}

[1] Hamza, N., H.,2012, " Evaluation of water quality of diyala river for irrigation purposes", Diyala Journal of Engineering Sciences, Vol.5 (2), pp. 82-98.

[2] Mohammed, R., A., 2013, " Water quality index for Basrah water supply ", Eng. \& Tech. Journal, Vol.31(8), pp. 1543-1555.

[3] Ravikumar, P., Somashekar, R. K., and Mhasizonuo, A., 2011, " Hydrochemistry and evaluation of groundwater suitability for irrigation and drinking purposes in the Markandeya River basin, Belgaum District, Karnataka State, India" , Environmental Monitoring and Assessment, Springer Science, Vol. 73(1), pp. 995-996.

[4] Hamid, I., Yahya B., Faheem, A. and Arif, I. 2012, "Effluent Quality Parameters for Safe use in Agriculture", Technology \& Medicine Open Access book publisher. Kalra, Y. P., \& Maynard, D. G.,1991, "Methods manual for forest soil and plant analysis", Information report NOR-X-319, Northwest Region, Northern Forestry Centre, Forestry Canada.

[5] Kareem, S., Al-Mamoori, and Al-Maliki, L., 2016, "Evaluation of suitability of drainage water of al-hussainia sector (kut iraq) to irrigate cotton crop", Kufa Journal of Engineering, Vol. 7(1), P.P.67-78.

[6] Nishanthiny, S.C., Thushyanthy, M., Barathithasan, T. and Saravanan, S., 2010, "Irrigation Water Quality Based on Hydro Chemical Analysis, Jaffna, Sri Lanka", American Eurasian J. Agric. \& Environ. Sci., Vol. 7(1), pp100102.

[7] Richards, L. A. ,1954, "Diagnosis and improvement of saline and alkali soils U.S. Salinity laboratory staff", USDA Handbook, pp 60-160.

[8] Ravikumar, P. and Somashekar, R. K. , 2013, "A geochemical assessment of coastal groundwater quality in the Varahi river basin, Udupi District, Karnataka State, India", Arabian Journal of Geosciences, Vol 6(6), p.p. 1855-1870.

[9] Wilcox, L.v., 1955, "Classification and Use of Irrigation Water", Vol. 969, Washington, D. C., United States Department of Agriculture.

[10] Ayers, R.S. and Westcot , D.W., 1985, "Water Quality for Agriculture," Irrigation and Drainage", Paper No. 29, FAO, Rome.

[11]Adam $\mathrm{H}$. "Assessment of water quality and soil properties for irigation in the horticultural crops producing areas of alhegaina, north kordofan state sudan",2014, M.Sc. Thesis, School of Agriculture and Enterprise Development, Kenyatta University.

[12] Khalil, A. A., and Arther, V., 2010, "Irrigation Water Quality Guidelines", Reclaimed Water Project, Jordan Valley Authority and German Technical Cooperation". 
[13]Al-Saady, Y., and Abdullah, E., 2014, "Water Quality of Tigris River within Missan Governorate eastern part of the Mesopotamia Plain - Iraq", Journal of Babylon University /Pure and Applied Sciences, Vol.22 (9), p.p. 24892502.

[14]Ramesh ,K. and Srinithi, K., 2014," Hydrochemical Characteristics of Groundwater in Mayiladuthurai Block of Nagapattinam District, Tamil Nadu", International Journal of ChemTech Research, Vol.6(14), pp. 56985708. 